\title{
Value Creation through IT-supported Knowledge Management? The Utilisation of a Knowledge Management System in a Global Consulting Company
}

\author{
Karlheinz Kautz and Volker Mahnke \\ Copenhagen Business School, Frederiksberg, Denmark
}

\author{
khk.inf@cbs.dk vm.inf@cbs.dk
}

\begin{abstract}
:
Although many consulting companies have introduced IT-supported knowledge-management systems, and proponents of the literature continue to advocate knowledge management as a key to competitive advantage in consultancies, many knowledge management systems have fallen short of expectation in companies that have adopted them. However, empirical studies regarding the performance implications of these systems are missing. This paper reports such an empirical, explorative study identifying the extent as well as impediments of the utilization of an IT-supported knowledge management system in a large, global consulting company. The main findings are that the majority of the IT users are not familiar with the knowledge management framework of the company; still the knowledge management system is used by 3/4 of all respondents, but mainly to search for general information, much less to participate in competence networks to develop shared knowledge assets. The knowledge management system is not used as the primary repository and communication media for knowledge assets. The limited use is explained by the practitioners as being caused by lack of time and their perception of the system as a slow and poorly structured technical infrastructure. These and other findings are discussed with regard to the current understanding of knowledge management as presented by the literature, and important issues with regard to future research integrating individual, organisational, technical and economical perspectives of knowledge management are raised.
\end{abstract}

Keywords : knowledge management, adoption and utilisation, transaction costs, global consulting

\section{Introduction}

Knowledge management - a set of management activities aimed at designing and influencing processes of knowledge creation and integration including processes of sharing knowledge - has emerged as one of the most influential new organizational practices. Numerous companies have experimented with knowledge management initiatives in order to improve their performance, and the literature advocating the benefits of knowledge management has virtually exploded (e.g. Nonaka \& Takeuchi, 1995; Choo, 1998; Boisot, 1998; vonKrogh et al., 2000; Easterby-Smith et al., 2000). Indeed, many writers go so far

Material published as part of this journal, either on-line or in print, is copyrighted by the publisher of Informing Science. Permission to make digital or paper copy of part or all of these works for personal or classroom use is granted without fee provided that the copies are not made or distributed for profit or commercial advantage AND that copies 1) bear this notice in full and 2) give the full citation on the first page. It is permissible to abstract these works so long as credit is given. To copy in all other cases or to republish or to post on a server or to redistribute to lists requires specific permission and payment of a fee. Contact Editor@inform.nu to request redistribution permission. as to argue that knowledge has taken precedence over traditional organizational resources, such as capital and land in value creation. While this might not be true for all types of companies, in global consulting - the empirical context of the current work - knowledge is certainly a key resource, as consulting services mainly consist of ideas (know what) and methods (know how). Thus, it should come as no surprise, that consulting companies are some of the early adaptors of knowledge management systems that are often 
supported by IT solutions.

Despite numerous claims in the popular literature, empirical evidence with regards to the performance implications of knowledge management systems remains sparse and inconclusive. With few exceptions (Hansen, 1999; Gupta \& Govindarajan, 2000; Szulanski, 2000), evidence is based on qualitative case studies (see, for example, Hansen et al., 1999; Brown \& Duguid, 2000; Huysman, 2000; Kautz \& Tha ysen, 2001) and remains focused on identifying enabling factors for sub-processes of knowledge management systems. The implications for value creation through knowledge management in general, and IT-supported knowledge management systems in particular, however, remain claimed rather than empirically corroborated.

The lack of empirically grounded - theoretical - guidance for managerial practice is the more regrettable the more one realises that, after first attempts to implement IT-supported knowledge management systems, many managers seem to be disappointed with the effectiveness of knowledge management as a managerial instrument to achieve competitive advantage. In a recent study by Rigby (2001), over 214 executives from different North American and European companies evaluated the effectiveness of 25 top management tools. On a scale from 1 (highly dissatisfied) to 5 (highly satisfied), knowledge management ranks $25^{\text {th. }}$. Clearly, knowledge management today is less favourably regarded than in the past. Part of the reason, as we will argue and empirically demonstrate below, is that companies have invested heavily in IT technology to support knowledge management initiatives but, simultaneously, have neglected important issues of transaction costs relating to people's interest and cognition as well as to the transaction infrastructure that impede effective knowledge management systems' utilization. Our explorative empirical study reveals that the majority of users of an IT-supported knowledge management system in a large consultancy are not familiar with the firm's knowledge management framework, lack clear incentives to do so, and face high transaction costs related to the system's infrastructure. Still the knowledge management system is used by $3 / 4$ of all respondents, but mainly to search for general information, much less to participate in competence networks to develop shared knowledge assets. The knowledge management system is not used as the primary repository and communication media for knowledge assets. Based on our explorative study, we argue that adoption of IT-supported knowledge management system requires both attention to people and information technology.

While the relative emphasis on either people or information technology in the design of knowledge management systems may depend on alternative types of potential economies available to the company (Hansen et al., 1999), we suggest that systematic attention to important transaction costs relating to knowledge codification and sharing, to incentives of system users, and the organizational and technical transaction-infrastructure is crucial to conceptualize value creation theoretically and guide managers and employees during the adoption and utilization of IT-supported knowledge management systems.

The remainder of the paper proceeds as follows: Section two outlines recent theoretical arguments on value creation through IT-supported knowledge management systems. Section three describes the research context and approach to the case organization under investigation, and section four presents the results of the explorative empirical study of an IT-supported knowledge management system in a large, global consulting company. These results are discussed in section five, and conclusions are drawn and further research questions raised in section six.

\section{The Current Literature: IT-supported Knowledge Management in Consulting Companies}

If the purpose of consulting companies is to generate value from accessing (Haanes, 1997), creating (Nonaka, 1994), replicating (Kogut \& Zander, 1992, 1995), integrating (Grant, 1996; Prahalad \& Conner, 1996), leveraging (Prahalad \& Hamel, 1994) and commercializing idiosyncratic knowledge, ITsupported knowledge management systems may be expected to contribute to competitive advantage. In 
particular, above average returns accrue to companies to the extent that (1) the use of idiosyncratic knowledge in product-market strategies yields a superior resource position (Wernerfelt, 1984), (2) this position is temporarily non-imitable (Lippman \& Rumelt, 1982; Rumelt, 1984; Peteraf, 1993), (3) underlying resources are hard to substitute (Barney, 1991), and (4) the resulting value is appropriable by the company (Grant, 1996). In contrast to resources, which can be easily traded and are widely accessible through markets, idiosyncratic and scarce knowledge qualifies as a strategically significant resource (Winter, 1987) that a company may seek to leverage and develop with the help of an IT-supported knowledge management system (Alavi \& Leidner, 1999).

Recently, many authors have argued that IT-supported knowledge management systems are an important value-adding component of knowledge management initiatives (e.g. vonKrogh et al., 2000; Dave nport \& Prusak, 1998). For example, IT-supported knowledge management systems foster the systematic identification of de-central knowledge and expertise, encourage converting knowledge into manifest forms (e.g. explicit knowledge), and make information accessible to others in the firm for local use in terms of knowledge re-use and as input for knowledge-development. Thus, IT-supported knowledge management systems may ease the integration of dispersed knowledge (Grant, 1996), speed up the replication of best practices across time and place (Nelson \& Winter, 1982), avoid double invention, facilitate leveraging across uses and users (Quinn, 1992; Quinn et al. 1996) to achieve economies of scale and scope, contribute to the co-location of knowledge and tasks (Jensen \& Meckling, 1992), and reduce costs of searching and transforming available knowledge for local use (Hedlund, 1994). If so, they can contribute to the competitive advantage of a consultancy, for example, through process improvements and service differentiation (Leonard-Barton, 1995).

While potential benefits of IT-supported knowledge management systems have been addressed theoretically in the literature less is known about how these can be realized in practice. Some authors suggest (e.g. Cook \& Yanow, 1993) that knowledge maybe in part a codifiable commodity, which can be stored and accessed in databases. In this view IT-supported knowledge management systems act as organizational memory that exceeds individual cognitive constraints. IT-supported knowledge management systems can aid individual cognitive processes of memorizing and organizing information. Others suggest, when knowledge remains a personal property, then the idea of mere cognitive, de-contextualized acquisition of knowledge is inadequate in a context where people act together to develop new knowledge (Lave, 1993; Elkjær, 1999). Nonaka (1994) argued earlier that tacit knowledge cannot simply be considered as information as it is re-created and re-constituted through interactive, continuous social networking activity - an activity that is performed through participation in, what Brown \& Duguid (1991) call, communities-of-practice. Nonetheless, it can be argued that IT-supported knowledge management systems can create a forum and context that fosters knowledge creation (vonKrogh et al., 2000; Boland \& Tenkasi, 1995). Kautz \& Thaysen (2001) put forward that the distinction of different types of knowledge, as well as of individual cognitive knowledge processes as opposed to collective knowledge processes, that take place in communities-of-practice makes sense for analytical reasons, but that the two approaches are closely intertwined and supplement each other. In line with this argument and integrating both arguments, Hansen et al. (1999) propose two overall strategies for the design of knowledge management systems. The so-called codification strategy relies on carefully structured databases and should be applied in a context where a company provides standardised, mature products and services, which can be described in written documents and stored in databases. The other strategy, called personalisation strategy, where technology is only used to mediate communication, should be applied where customised, innovative products and services are provided based on personal collaboration.

When companies seek to exploit potential economies of IT-supported knowledge management systems not only the potential benefits as discussed in the current literature need to be understood, but also investments and costs of IT supported knowledge management systems should be considered. However, the theoretical arguments on value creation through IT supported knowledge management as presented 
Value Creation

in existing research fail to systematically account for transaction costs of such systems. Only a few authors and studies advocate the significance of the transaction costs of (1) codifying knowledge (see for example Nelson \& Winter, 1982) (2) sharing - contributing, gathering, searching, assessing - knowledge (Hedlund, 1994; Mahnke, 1999) (3) the incentives for codification and sharing knowledge (Harper, 1997) and (4) setting up an organisational and technical infrastructure (EIU, 2000).

However, due to the lack of a comprehensive conceptualisation of knowledge management, including a transaction cost based economical perspective and lack of suitable data, empirical studies regarding the performance implications of the different approaches to the design and use of IT-supported knowledge management systems are missing. The research presented here provides such an empirical, explorative study identifying the degree and extent as well as impediments of the utilization of an IT-supported knowledge management system in a global consulting company and can be considered as a first step towards an integrative framework for understanding knowledge management from both a individual, organisational, technical and economical perspective.

\section{The Research Context and Research Approach for the Empirical Analysis}

\section{The Research Context}

The case organisation is one of the world's largest IT service providers with more than 100,000 employees in more than a 100 countries. The company distinguishes a number of business areas, which are formally organised in a number of departments. Each employee is assigned to one business area and one department, and work is performed in projects. Staff performance is measured with respect to chargeable customer project time. Business areas reach across formal department boundaries and the company has about 60 so-called knowledge networks, which organise employees within a business area in special interest groups. The organisation has - based on industry's best practice and interviews and workshops with its own consultants - developed a framework to deal with knowledge in the organisation. This initiative started in 1995 in one country. Knowledge is regarded as an asset and as intellectual capital. It is seen as a prerequisite for achieving customer satisfaction and profit. Knowledge management aims at creating and structuring knowledge assets. This is believed to enable creation, sharing of locally dispersed knowledge and to (re-)use it to ultimately deliver value to customers and stakeholders. As one manager puts it, "To serve our customers well, we need people to look beyond their immediate project and tasks to recognize that they are part of a wealth of knowledge production efforts in a global consultancy - our knowledge management framework is designed to further this recognition."

The framework is based on the company's official value system that promotes sharing as part of good corporate citizen behaviour. It also relates to the company's approach to maintain staff commitment through measurable performance goals, complemented with an economical incentive scheme. The company stresses knowledge management support when it comes to the introduction of new procedures and tools; as a mana ger explains, "Our knowledge management framework seeks to support the consultant's project work and individual development through making technological solution themes and guidelines available, helps to locate experts and projects, and supports learning from, for example, sales experiences of others - we seek to co-locate knowledge to the point of action." At the kernel of the framework are several IT-supported knowledge networks. These evolve around knowledge themes, such as 'reducing selling and delivery cycle time,' 'emergent technological opportunities,' 'sales enhancement,' and 'employee satisfaction' Knowledge networks also seek to capture topic specific knowledge about up-todate issues, like e-business, IT security, and ERP systems, or about timele ss subjects, like project management and organisational change. Each of these networks organises between 100 and 2000 employees. Until the end of 1999 a third of all employees were officially registered as members of the overall knowledge management system. 
No figures concerning the expenditures for the original knowledge management infrastructure were made available by the organisation. Recent studies (EIU, 2000) however report that the costs for establishing IT-supported knowledge management involving more than 500 employees, depending on the project's scope, may range between $\$ 200,000$ and $\$ 10,000,000$. Although it is hardly possible to draw any solid conclusions from such numbers, the company must have invested a significant amount of money in the building of the infrastructure. The company employed over 300 professionals to implement its original knowledge management system. Many of these were concerned with helping project teams to initially codify and classify relevant knowledge and to select and package it in suitable form for access by potential users.

\section{Legitimisation of knowledge content in networks}

Although the knowledge networks are considered informal, they are institutionalised in a fairly formal way. Each network, as well as each area of general competence, has a formal, usually part-time and in a few exceptions full time, employed leader, a routing secretary transferring submitted knowledge contributions to the respective topic experts, and a steering board of up to 20 practitioners, the so-called topic experts. They decide whether and in what form submitted knowledge is made accessible to all other network members. In addition, a network distinguishes between two groups, the so-called educated practitioners and the usual practitioners who have different access rights to the available material. Their role is to provide, comment and use the knowledge at their disposal. However, a consultant critically remarked, "While all members of the knowledge network can access all knowledge content not all seem welcome to contribute to it."

The knowledge management process is organised in five distinct and one overall embedded activities. In activity one, knowledge is captured or procured; then it is rated and esteemed. If approved it is edited, formatted, categorised and structured. In activity four it is then published and, finally, it is used. The overall surround ing process deals with the continuous further development of the framework and the contents of the knowledge bases. All these activities are in principal supported by all employees through their contribution of new knowledge, as well as their feedback and comments concerning existing knowledge. However, although they are to be performed by different groups of employees, the members of the steering board largely execute the activities.

\section{IT-support of the knowledge management framework}

Technically the knowledge management framework is supported by a web-based information system, which itself is based on a well-known groupware platform and database system. Here all submitted and approved knowledge is stored and accessible in the form of documents in databases - one database is defined per knowledge network, and the usual groupware applications, such as email, discussion fora, chat rooms, and calendar functions, are provided in addition. All documents are classified according to their topic and a typification scheme, which distinguishes, for example, method descriptions, document templates, practical tips, marketing material, and biding components. They are, of course, searchable according to a number of criteria.

The knowledge management framework and its IT support are geared towards the organisation's model for performing customer projects. This model consists of five phases: Phase one consists of marketing activities where knowledge utilisation in form of company presentations can and should take place, and where in phase five, the project closure, knowledge - in the rhetoric of the company - should be harvested and submitted to the knowledge management system. The other phases are concerned with carrying out the actual project, and, again, the knowledge available in the knowledge management system should be used here.

In the following the research approach applied in the study is presented, and then a closer look is taken at how in particular the IT support of the knowledge management system is used. 


\section{The Research Approach}

The case analysis proceeds based on both qualitative interview and survey data among user groups. We conducted a number of formal and informal interviews and studied company documents concerning its policy towards knowledge management. We also gained access to data concerning the utilisation of the databases underlying the IT support for knowledge management. The main emphasis was on collecting quantitative data with regard to the usage of the company wide web-based IT components. For this purpose a survey instrument with 35 questions and about 200 attributes was developed. Most of the que stions contained multiple-choice type answers, a few also allowing for qualitative statements. The questionnaire contained several distinct parts to collect personal data about the respondents, their general use of technology, their attitude towards the company's knowledge framework and their usage, or nonusage, of the company's IT support explicitly dedicated towards knowledge management. The questionnaire was piloted twice and, in the company's technology friendly environment, distributed via a webbased solution. As the study was of an explorative and analytical character, no hypotheses were formulated and tested, nor were any sophisticated statistical tests run.

A specific problem in a population of over 100,000 members was the identification of a representative sample. We had access to the data documenting the total create, read, update and delete activities in the 60 databases that administer the documents for the KMS for a period of four months in the beginning of the year 2000. An investigation of a sample of $10 \%$ of the company's employees had shown that $44 \%$ of these were content as opposed to $16 \%$ who were not content with the IT support for knowledge management. The rest were neither particularly satisfied nor especially dissatisfied. On this overall positive background the research objective was to get an impression of the actual utilisation, and we decided to collect data from a top user and one average user group out of the absolute top 15 networks and to contrast these when significant. With the help of the following four criteria: (1) number of documents in the knowledge network database, (2) number of submitted documents to the knowledge network database, (3) number of opened documents and (4) number of practitioners in relation to number of opened documents, we identified a top group -i.e. the group which according to all four criteria was among the top three user groups. To give the reader an impression, concerning criteria (1) the chosen group had about 950 documents in its base as compared to 2800 of the absolute top group, (2) there had been 115 submissions as compared to a top 340, with regard to criteria, (3) the chosen group represented the absolute top with 19,000 opened documents, and, with regard to criteria, (4) the group had 14 opened documents on average per member as opposed to 15 for the absolute top. For the average user group all numbers where naturally lower.

The top user group consisted of approximately 1400 practitioners. Thus, we decided to address only those who had at least opened 10 documents during the period of investigation. This left us with 304 employees who received the questionnaire. Finally, with regard to the average group, we left it to the regional managers in the Northern European countries to spread the questionnaire, which lead to the distribution of a further 229 questionnaires.

We received 125 (ca. 23\% response rate) usable answers of which 62 came from the top group and 63 from the average group. In the top group the distribution was approximately half from Europe (plus one from South Africa), 40\% from the Americas, and the rest from the Asia-Pacific area. For the average group all answers were, of course, from Northern Europe. As we could not find any significant differences between the members of the top and the average group, nor with regard to the different geographic areas, these are as a rule not considered in the following presentation of the results. However, some tables showing the survey results for both groups have been included to illustrate their slightly different positions.

An oddity with regard to the two groups was uncovered through a control question that showed that only $58 \%$ who, according to the database data, had at least 10 documents opened in the investigated period 
considered themselves as members of this knowledge network, whereas $28 \%$ of the average group, representing formally a different network, also considered themselves as members of the network that represented the top user group. This indicates a discrepancy between the company's official concept of (membership in) an informal network and the employees' understanding of the concept of knowledge network. We will take up this finding later again.

\section{Results: Knowledge Management in the Global Consulting Company}

In total, $72 \%$ of all respondents believe that well up to $50 \%$ of the organisation's knowledge can be codified in written documents. The precise distribution is as follows: $24 \%$ believe that up to $20 \%$ of all knowledge can be codified, $22 \%$ think that up to $40 \%$ can be codified, and $26 \%$ say that $50 \%$ can be codified.

\begin{tabular}{|l|l|l|l|l|l|l|}
\hline & $\begin{array}{c}\text { All } \\
\text { abs. no. }\end{array}$ & $\begin{array}{c}\text { All } \\
\%\end{array}$ & $\begin{array}{c}\text { Top group } \\
\text { abs. no. }\end{array}$ & $\begin{array}{c}\text { Top group } \\
\%\end{array}$ & $\begin{array}{c}\text { Average group } \\
\text { abs. no. }\end{array}$ & $\begin{array}{c}\text { Average group } \\
\%\end{array}$ \\
\hline $\begin{array}{l}\text { Talk/discuss with } \\
\text { colleagues }\end{array}$ & 100 & $80 \%$ & 48 & $77 \%$ & 52 & $83 \%$ \\
\hline $\begin{array}{l}\text { Search KMS data- } \\
\text { bases }\end{array}$ & 90 & $72 \%$ & 55 & $89 \%$ & 35 & $56 \%$ \\
\hline Search Internet & 88 & $70 \%$ & 50 & $81 \%$ & 38 & $60 \%$ \\
\hline Search Intranet & 80 & $64 \%$ & 42 & $68 \%$ & 38 & $60 \%$ \\
\hline Read book on topic & 51 & $41 \%$ & 21 & $34 \%$ & 30 & $48 \%$ \\
\hline $\begin{array}{l}\text { Use personal, exist- } \\
\text { ing knowledge }\end{array}$ & 43 & $34 \%$ & 19 & $31 \%$ & 24 & $38 \%$ \\
\hline Take a course & 34 & $27 \%$ & 10 & $16 \%$ & 24 & $38 \%$ \\
\hline Ask around & 18 & $14 \%$ & 10 & $16 \%$ & 8 & $13 \%$ \\
\hline Use KMS helpdesk & 7 & $6 \%$ & 6 & $10 \%$ & 1 & $2 \%$ \\
\hline
\end{tabular}

Table 1: Information Sources

(all respondents, percentage given with regard to the total responses within the respective group)

Concerning the question about which sources they use when in need of information regarding a specific topic (see Table 1), $72 \%$ of all respondents answer that they use the data bases of the knowledge management system. More respondents, namely $80 \%$, talk to or discuss directly with colleagues; $70 \%$ search the internet, $64 \%$ use the company's general intranet, $41 \%$ read a book on the subject and $27 \%$ take an educational course, only $6 \%$ consult the knowledge management system's help desk. All respondents use email and $65 \%$ a groupware application called teamrooms to communicate and collaborate with colleagues; $58 \%$ use something other than the knowledge management system as a repository to store valuable information; half of these use a document library which is also a component of the company's groupware environment.

\section{Users' Attitudes towards the IT-supported Knowledge Management System}

The large majority (89\%) of the system users believes that the IT-supported knowledge management system provides the company with a competitive advantage. Concerning the advantages of the system, $66 \%$ of them see the biggest benefit of the system is the fact that - according to their perception - all codified knowledge is, in principle, available through it, and $64 \%$ see its benefits in enabling re-use of documents. Furthermore, 35\% value the ability to find contacts, 33\% appreciate it as support for their collaboration, but only $25 \%$ see the advantage in the opportunity to create knowledge and even less, 
namely $20 \%$, view it as an advantage that they can contribute to the collective knowledge. Finally, only $7 \%$ see its merits for giving explicit feedback concerning the stored knowledge.

\section{Utilisation of the Knowledge Management System's Functionality}

On the direct question whether they use some functionality of the knowledge management system $76 \%$ answered with "yes." 27\% use it up to one hour a week, $43 \%$ between 1 and 5 hours and $15 \%$ more than 5 hours a week, and nearly a third (29\%) use it in every project assignment. Based on the research framework one would expect that all respondents from the top user group would utilise the system; however, three of them have abandoned usage and give as a reason that the system is not useful in their current job or that the system is too slow to provide help. In the average user group $57 \%$ of the respondents use the system at the time of the investigation.

\begin{tabular}{|l|l|l|l|l|l|l|}
\hline & $\begin{array}{c}\text { All } \\
\text { abs. no. }\end{array}$ & $\begin{array}{c}\text { All } \\
\%\end{array}$ & $\begin{array}{c}\text { Top group } \\
\text { abs. no. }\end{array}$ & $\begin{array}{c}\text { Top group } \\
\%\end{array}$ & $\begin{array}{c}\text { Average group } \\
\text { abs. no. }\end{array}$ & $\begin{array}{c}\text { Average group } \\
\%\end{array}$ \\
\hline General information & 58 & $61 \%$ & 35 & $59 \%$ & 23 & $64 \%$ \\
\hline $\begin{array}{l}\text { Project profiles and ex- } \\
\text { perience }\end{array}$ & 50 & $53 \%$ & 33 & $56 \%$ & 17 & $47 \%$ \\
\hline Knowledge networks & 43 & $45 \%$ & 29 & $49 \%$ & 14 & $39 \%$ \\
\hline Biographies & 19 & $20 \%$ & 14 & $25 \%$ & 5 & $14 \%$ \\
\hline $\begin{array}{l}\text { Reusable software com- } \\
\text { ponents }\end{array}$ & 18 & $19 \%$ & 11 & $19 \%$ & 7 & $19 \%$ \\
\hline $\begin{array}{l}\text { Topic based collabora- } \\
\text { tion }\end{array}$ & 16 & $17 \%$ & 11 & $19 \%$ & 5 & $14 \%$ \\
\hline Project advice & 12 & $13 \%$ & 8 & $14 \%$ & 4 & $8 \%$ \\
\hline Discussion groups & 5 & $5 \%$ & 2 & $3 \%$ & 3 & $6 \%$ \\
\hline Yellow pages & 5 & $5 \%$ & 3 & $5 \%$ & 2 & $1 \%$ \\
\hline
\end{tabular}

\section{Table 2: Usage of the Knowledge Management IT Tool Functions}

(tool users only, percentage given with regard to the total users within the respective group)

The differing percentages concerning system use may be an indication that not all of the users are familiar with the company's knowledge management framework and rhetoric and indeed only $69 \%$ of all users confirm that they know the framework and its defined processes. This has to be seen in relation to the fact that only $49 \%$ of the practitioners have gone through a formal training which might entail the danger that not all use the knowledge management system in the intended way. $69 \%$ of the users state that they apply the system to collect information, but that they also use other sources and media to do so, such as a local hard disk (49\%), paper $(25 \%)$ or other databases $(25 \%)$ and that they rely on their own memory (44\%). With regard to the functions provided by the IT system (see Table 2) $61 \%$ use the tool to get general information, $53 \%$ to access project descriptions, $45 \%$ of the users apply it to participate in knowledge networks, $20 \%$ to search for biographies, $19 \%$ to find reusable software components, $17 \%$ to co-operate with colleagues on dedicated topics, $13 \%$ to get advice for project work, and $5 \%$ to participate in discussion groups and to use the yellow pages of the company.

However, to the question of why and how they use the system (see Table 3), 66\% answer that they browse the system in general for useful documents, $41 \%$ to find project profiles, $17 \%$ to find a knowledgeable colleague, $15 \%$ to find biographies and $9 \%$ to find CVs. $48 \%$ use the system as a repository for valuable knowledge and documents, but only $22 \%$ as the primary repository for this purpose. Just $52 \%$ submit anything to a network and of these $41 \%$ do that 1 to 5 times a year and only $11 \%$ do so more often; $46 \%$ never submit anything. 


\begin{tabular}{|l|l|l|l|l|l|l|}
\hline & $\begin{array}{c}\text { All } \\
\text { abs. no. }\end{array}$ & $\begin{array}{c}\text { All } \\
\%\end{array}$ & $\begin{array}{c}\text { Top group } \\
\text { abs. no. }\end{array}$ & $\begin{array}{c}\text { Top group } \\
\%\end{array}$ & $\begin{array}{c}\text { Average } \\
\text { group } \\
\text { abs. no. }\end{array}$ & $\begin{array}{c}\text { Average } \\
\text { group } \\
\%\end{array}$ \\
\hline $\begin{array}{l}\text { To browse for useful in- } \\
\text { formation }\end{array}$ & 63 & $66 \%$ & 40 & $68 \%$ & 23 & $64 \%$ \\
\hline To store knowledge assets & 46 & $48 \%$ & 32 & $54 \%$ & 14 & $39 \%$ \\
\hline To find project profiles & 39 & $41 \%$ & 30 & $51 \%$ & 9 & $25 \%$ \\
\hline $\begin{array}{l}\text { To find a knowledge-able } \\
\text { colleague }\end{array}$ & 16 & $17 \%$ & 14 & $24 \%$ & 2 & $6 \%$ \\
\hline To find biographies & 14 & $15 \%$ & 9 & $15 \%$ & 5 & $14 \%$ \\
\hline To find a CV & 9 & $9 \%$ & 7 & $12 \%$ & 2 & $6 \%$ \\
\hline & & & & & & \\
\hline $\begin{array}{l}\text { As the primary store for } \\
\text { knowledge assets }\end{array}$ & 21 & $22 \%$ & 16 & $27 \%$ & 5 & $14 \%$ \\
\hline
\end{tabular}

Table 3: Reasons for and Utilisation of the Knowledge Management IT Tool

(tool users only, percentage given with regard to the total users within the respective group)

$33 \%$ submit something that they themselves consider new knowledge (an intellectual asset) and 16\% update existing knowledge, whereas $63 \%$ answer that they search for what they consider an intellectual asset.

The survey did not investigate whether those who submit often are members of the steering boards that have the overall responsibility for the functioning of the knowledge management system or whether they are usual users. Concerning feedback, $71 \%$ never give feedback to existing material and only $16 \%$ do so 1 to 5 times a year and the rest less.

The system is used in all project phases, but mainly in the actual sales' phase when a contract is drawn (35\%) and when the project is performed (33\%). Only 14\% use the system when a project is closed, which according to the framework should be the phase where project experience in written form should be submitted to the knowledge bases. However, somewhat contradictory, $38 \%$ answer that they use the system to reap knowledge in a project assignment.

With respect to the respondents' job functions, $93 \%$ of all consultants who answered identified the mselves as users, but only $62 \%$ of all replying technical staff did so. This supports the numbers describing the use purposes of the system for project work.

Again the somewhat different numbers indicate problems with the understanding of the system's intentions and the underlying framework.

\section{Utilisation Problems and Reasons for Non-Adoption}

There are a couple of reasons why people are so hesitant, which are explicitly stated by the respondents of the survey. Only $31 \%$ of the system users put forward that the documents are easy to find and that the knowledge base is well structured, and only $20 \%$ think that the newest knowledge is available, whereas $31 \%$ think that the provided information is not up-to-date. Furthermore, $29 \%$ declare that the databases are too big and $23 \%$ that they often cannot find what they need. Finally, $19 \%$ say that there is simply too much information on the company Web. There are also a few who answer that the approval process that is performed by the steering boards specially assigned to this task - although only part-time - is too slow and not accurate enough. Yet, the biggest obstacles seem to be that the technical infrastructure, namely the internal network, is too slow $(60 \%)$ and that the employees who are paid based on hours billed to customer projects do not feel that they have time to explore the system (38\%). Those who do not use the system confirm this tendency: $50 \%$ of them state that they do not have the time to do so. A further $27 \%$ 
express that the information is not suitable for them ,and $23 \%$ answer that they never found the information they were looking for and that they, therefore, have stopped using the system. They use instead exclusively the above-mentioned media, namely databases (30\%), local hard disks (23\%), network drives $(23 \%)$ and paper archives $(20 \%)$ and rely on their own memory $(40 \%)$.

The utilisation problems and reasons for not adopting the knowledge management system have been clearly expressed and stated in the following way by one of the involved network managers: ... [t]he concept of KM for mutual benefit seems self-evident for the enthusiasts, which only increases their puzzlement when others in their organisation show apathy or even negative interest in the concept. If there is no offsetting benefit for sharing knowledge in terms of money and recognition, or the process by which one does so is arcane or bureaucratic, or it is difficult to find the right fora, then organizational costs rise and participation drops proportionally."

\section{Discussion}

The data material can be interpreted from different perspectives. From one point of view it can be argued that the organisation has problems with its approach to knowledge management. Several reasons for what some might consider as relatively low adoption and use of the IT support and its underlying framework have been given by the respondents themselves. Technical advances concerning the internal network capacity might increase the utilisation of the knowledge management system. The same is valid for organisational amendments with regard to the relation of time spent directly on client assignments and time spent on knowledge work. Better information and more training about the framework and its IT support will possibly enhance the situation. Improving the structuration and approval process will probably also have a positive effect, but the given reasons might also be an indication for deeper lying problems.

As described earlier, Hansen et al. (1999) propose two overall strategies for knowledge management, of which one always should be the primary one and the other the supporting secondary one. The codification strategy relies on carefully structured databases and should be applied in a context where a company provides standardised, mature products and services, which can be described in written documents and stored in databases. The other strategy, the personalisation strategy, where technology is used only to mediate communication, should be applied where customised, innovative products and services are provided based on personal collaboration.

The balance of the two strategies is delicate and requires that the company has a clear understanding of its business. It might be that the organisation under investigation here does not have such a clear, shared vision. It seems to heavily rely on a codification strategy where a personalisation strategy might be more adequate. At least the fact that only $28 \%$ of the respondents believe that more than $50 \%$ of the organisation's knowledge can be codified points into this direction.

Another result also needs more analysis. The respondents complain that there is too much information in the databases and that the information is not properly structured. The organisation has good intentions with the establishment of approval teams and thus follows current best practice (See Brown \& Duguid (2000) for another example). It might however indicate that the organisation does not involve the right people in the approval process. Brown \& Duguid (2000) strongly advocate involving the practitioners who produce and apply the knowledge, not only in the submission and general feedback processes, but also in the approval process. If only managers and project leaders fill the databases, there is a risk that the repositories contain only what they think is useful for their employees and not what is actually valuable for them. In such cases, the contents of the databases might also appear fragmented and not be used, as shown by, for example. Robey et al. (2000).

These authors also point to another technology related problem. Knowledge archived in a database has to be taken as it is. There is little or no possibility to interactively negotiate and clarify its contents. To 
elucidate uncertainties social interaction is still necessary. Such interaction also supports getting known to each other and to build up trust - both characteristics, which according to Nonaka (1994) are mandatory for sharing knowledge. From this point of view the respondents' preference for a mixture of knowledge sources and especially communication media appears to be a natural choice to operate in a network of people supported by technology. Then, the achieved utilisation rate of the IT tool in general - although leaving room for improvement - can be considered as not that low.

When applying a transaction cost inspired perspective, our case inspection reveals several complications impeding the utilisation of IT-supported knowledge management in the global consulting company. Given that significant investments have been made to set up an organisational and technical infrastructure for knowledge management, the empirical findings point to a certain aspiration-performance gap. It seems evident that the employees in the case organisation assess codification and knowledge sharing transaction costs in terms of articulating, contributing, searching and accessing knowledge as too high with regard to the benefits and incentives they as individuals gain and receive. This in turn influences the value creation process for the company as a whole, because, as the case analysis indicates, important transaction costs relating to knowledge codification and sharing, to incentives of system users, and to the organisational and technical infrastructure are underestimated and paid little attention to relative to potential value creation through the adoption of IT-supported knowledge management.

While identifying these reasons for the limited or non-adoption is a first step to studying value creation and performance implications of IT-supported knowledge management, future empirical research has a need for, and will certainly benefit from, a sound conceptualisation of transaction costs associated with the use of such systems. First, when on this basis transaction cost data can be obtained, a comprehensive analysis of the impact of IT-supported knowledge management systems can be performed comprising individual, organisational, technical and economical considerations.

\section{Conclusions}

The preceding presentation and discussion of our research results have analysed the extent and some impediments of IT-supported knowledge management in a large, global consulting company. It has also pointed to some questions, both with respect to the organisation under investigation here and the field of knowledge management in general. These are partly related to the research method applied here. Together with the main findings they will now be summarised.

The study was explorative in nature and the purpose of the used survey instrument was to collect empirical data to get first indications concerning the objectives, the degree and the problems related to ITsupport for knowledge management with regard to value creation in global consulting firms. The research results show that the respondents were not familiar with, or have not understood, the knowledge management framework underlying the IT support. Clearly future research should directly inquire how the company's employees perceive the knowledge management framework and its constituting processes. It might also be interesting to correlate the different variables with regard to who is using which functionality for what reason and to what degree both in terms of frequency and time spent to get a more differentiated picture of user profiles and usage patterns.

On a more overall level, beyond conventional knowledge management studies, this research identified the need for a sound theoretical grounding of transaction costs as a prerequisite to integrate an economical perspective with individual, organisational and technical perspectives. This will allow for an in-depth analysis of value creation and performance implications of IT-supported knowledge management.

Finally, the study might be criticised for the size and selection of its sample. But even if the following results are biased and not representative for the whole organisation and the consulting industry as such, they are valid for a small, but important segment of the company's employees and, as such, show some note-worthy trends. In summary, the knowledge management system: 
Value Creation

- is used by $3 / 4$ of all respondents, about $2 / 3$ use it mainly to search for general information, about $1 / 2$ participate in competence networks

- is mainly used in the marketing phase of project acquisition

- is mainly used by consultants, and less by technical developers

- utilisation is limited due to the practitioners' lack of time

- is little used to participate in the development of knowledge assets

- is with regard to its various functions not used very much

- framework is not known to the majority of the KMS users

- is not used as the primary repository for knowledge assets

- is slow and has long answer times

- has an inscrutable structure and provides poor search results.

These results and the accompanying discussion give an interesting starting point for the company to consider its knowledge management approach and for the research community to perform further investigations.

\section{References}

Alavi, M, \& Leidner, D. E. (1999). Knowledge management and knowledge management systems : Conceptual foundations and research issues. INSEAD Working Paper.

Boisot, M. (1998). Knowledge assets: Securing competitive advantage in the information. Oxford, UK: Oxford University Press.

Barney, J. (1991). Firm resources and sustained competitive advantage. Journal of Management 17: 99-120.

Boland, R. J., \& Tenkasi, R. V. (1995). Perspective making and perspective taking in communities of knowing. Organization Science, 6: 350-372.

Brown, J. S., \& Duguid, P. (1991). Organisational learning and communities-of-practice: Toward a unified view of working, learning, and innovation. Organisation Science, 2 (1): 40-57.

Brown, J. S., \& Duguid, P. (2000). Balancing act: How to capture knowledge without killing it. Havard Business Review, May-June 2000, 73-80.

Choo, C. W. (1998). The knowing organization. Oxford, UK: Oxford University Press.

Cook, S. D. N., \& Yanow. D. (1993). Culture and organizational learning. Journal of Management Inquiry, 2 (4): $373-390$.

Davenport, T., \& Prusak, L. (1998). Working knowledge. Boston, MA: Harvard Business School Press.

Easterby-Smith, M., Crossan, M., \& Nicolini, D. (2000). Organizational learning: Debates past, present and future. The Journal of Management Studies, 38 (6): 783-796.

EIU. (2000). The learning organisation survey. The Economist Intelligence Unit.

Elkjær, B. (1999). In search of a social learning theory. In Easterby-Smith, M., Araujo, L., Burgoyne, J. (eds.), Organisational learning and the learning organisation, developments in theory and practice (75-91). London: Sage.

Grant, R. (1996). Toward a knowledge-based theory of the firm. Strategic Management Journal, 17: 109-122.

Gupta, A. K. \& Govindarajan, K. (2000). Knowledge flows within multinational corporations. Strategic Management Journal, 21: 473-496.

Haanes, K. (1997).Resource mobilization: Ownership vs. access. Academy of Management Conference Proceedings.

Harper, D. (1997). Entrepreneurship and the market process. An enquiry into the growth of knowledge. USA: Routledge. 
Hansen, M. T. (1999). The search-transfer problem: The role of weak ties in sharing knowledge across organisation subunits. Administrative Science Quarterly, 44: 82-111.

Hansen, M. T., Nohria, N., Tierney, T. (1999). What is your strategy for managing knowledge. Havard Business Review, March-April, 106-116.

Hedlund, G. (1994). A model of knowledge management and the n-form corporation. Strategic Management Journal, 15: 7390.

Huysman, M. (2000). Rethinking organizational learning: Analyzing learning processes of information system designers. Accounting, Management \& Information Technology, 10: 81-99.

Jensen, M. C., \& Meckling, W. H. (1992). Specific and general knowledge, and organizational structure. In Werin, L. \& H. Wijkander (eds.), Main currents in contract economics. Oxford, UK: Basil Blackwe ll.

Kautz, K. \& Thaysen, K. (2001). Knowledge, learning and IT Support in a small software company. Journal of Knowledge Management, 5 (4): 349-357.

Kogut, B. \& Zander, U. (1992). Knowledge of the firm, combinative capabilities, and the replication of technology. Organization Science, 3: 383-397.

Kogut, B. \& Zander, U. (1995). Knowledge of the firm and the evolutionary theory of the multinational corporation. Journal of International Business Studies, 24: 625-645.

Lave, J. (1993). The practice of learning. In Chaiklin, S. \& J. Lave (eds.), Understanding practice - Perspectives on activity and context (3-32). Cambridge, UK: Cambridge University.

Leonard-Barton, D. (1995). Wellsprings of knowledge: Building and sustaining the sources of innovation. Boston, MA: Harvard Business School Press.

Lippman, S. A., \& Rumelt, R. P. (1982). Uncertain imitability: An analysis of interfirm differences in efficiency under competition. Bell Journal of Economics, 13: 418-438.

Mahnke, V. (1999). The economic organisation of intellectual production. PhD dissertation. Copenhagen Business School, PhD series 12.1999. Samfundslitteraturforlag, Copenhagen, Denmark.

Nelson, R., \& Winter, S. (1982). An evolutionary theory of economic change. Ca mbridge, MA: The Belknap Press.

Nonaka, I. (1994). A dynamic theory of organizational knowledge creation. Organisation Science, 5 (1), 14-37.

Nonaka, I., \& Takeuchi, H. (1995). The knowledge creating company. Oxford, UK: Oxford University Press.

Peteraf, M. A. (1993). The cornerstones of competitive advantage: A resource-based view. Strategic Management Journal 14: 179-191.

Prahalad, C. K., \& Hamel, G. (1994). Competing for the future. Boston, MA: Harvard Business School Press.

Prahalad, C. K., \& Conner, K. R. (1996). A resource based theory of the firm: Knowledge versus opportunism. Organization Science, 7 (5): 477-501.

Quinn, J. B. (1992). Intelligent enterprise: A knowledge and service based paradigm for industry. New York: Free Press.

Quinn, J. B., Anderson, P., \& Finkelstein, S. (1996). Managing professional intellect: Making the most of the best. Academy of Management Executive, 74 (March-April): 71-80.

Rigby, D. (2001). Management tools and techniques: a survey. California Management Review, 43, 2: 129-143.

Robey, D., Khoo, H. M., \& Powers, C. (2000). Situated learning in cross-functional virtual teams: IEEE Transactions on Professional Communication, 43 (1) and Technical Communication (Joint Special Issue), 47 (1): 51-66.

Rumelt, R. P. (1984). Towards a strategic theory of the firm. Lamb, R. B. (ed.), Competitive Strategic Management (556570). Engelwood Cliffs, NJ: Prentice-Hall.

Szulanski, G. (2000). The process of knowledge transfer: A diachronic analysis of stickiness. Organizational Behavior and Human Decision Processes, 82 (1): 9-27.

vonKrogh, G., Ochijo, K., \& Nonaka, I. (2000). Enabling knowledge creation. Oxford, UK: Oxford University Press.

Wernerfelt, B. (1984). A resource-based view of the firm. Strategic Management Journal, 14: 4-12.

Winter, S. (1987). Knowledge and competence as strategic assets. In Teece, D. J. (ed.), Strategies for industrial innovation and renewal (159-184). Cambridge, UK: Ballinger. 


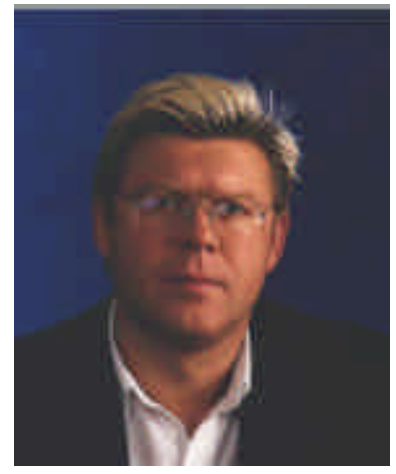

\section{Biographies}

Karlheinz Kautz is professor in systems development and software engineering at the Department for Informatics at Copenhagen Business School. He holds a $\mathrm{PhD}$ in systems development and MSc in software development. He is the chair of the IFIP TC 8 WG 8.6 on the adoption and diffusion of IT. His research interests are in systems development, knowledge management, IT diffusion and transfer, as well as software quality and software process improvement.

His work has been published internationally on conferences and in journals including Information Technology and People, IEEE Software, Information and Software Technology, Journal of Technology Studies, Journal of Human Computer Interaction, Software Process Improvement and Practice, Journal of

Computer Personnel, Organization, Scandinavian Journal of Information Systems, and Journal of Knowledge Management.

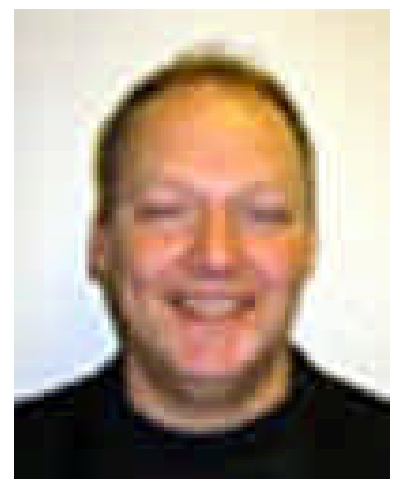

Volker Mahnke is associate professor in IT-strategy and innovation at the Department for Informatics at Copenhagen Business School. He holds a PhD in business economics and strategy and a MSc in international finance. His research interests are in strategic management of technology, knowledge management, and IT-enabled innovation. His work has been published internationally on conferences and in journals including Journal of Governance and Management as well as Management International Review. In addition, he has edited and co-authored books on Knowledge Management, Strategic Management, and Entrepreneurship. 